\title{
MODELING APATITE NUGLEATION IN THE HUMAN BODY AND IN THE GEOCHEMICAL ENVIRONMENT
}

\author{
NITA SAHAI \\ Department of Geology and Geophysics, 1215 West Dayton Street, University of \\ Wisconsin, Madison 53706; sahai@geology.wisc.edu
}

\begin{abstract}
This paper serves to show that under similar physicochemical conditions, universal chemical reaction pathways can be involved in the interactions of fluids, biomolecules and minerals, whether in the human body or in the geochemical environment. The concept is illustrated by comparing heterogeneous apatite nucleation at bone sialoprotein (BSP) surfaces, bioceramic implant surfaces and on marine, diatomaceous sediments where phosphorite deposits are formed. The present approach combines crystallographic considerations, experimental NMR data and ab initio molecular orbital calculations of NMR parameters to elucidate reactive site geometry, mineral nucleation and inhibition reaction pathways. This technique may be applicable in future investigations of biomineralization mechanisms.

The peptide sequence, $\mathrm{S}(\mathrm{P}) \mathrm{EE}$, is proposed to constitute an active site on BSP, where the three acidic groups are arranged at $60^{\circ}$ from each other. The equilateral triangle provides a stereochemical match for $\mathrm{Ca}^{2+}$ on the $(001)$ face of apatite. The analogous active site on silicate bioceramics is the cyclic silicate trimer or three-ring containing surface silanol groups. One possible reaction pathway for calcium phosphate (CaP) nucleation consistent with experimental ${ }^{31} \mathrm{P}$ NMR data involves the following steps: $\mathrm{Ca}^{2+}$ sorption at the active site and $\mathrm{HPO}_{4}^{2-}$ attachment resulting in the critical nucleus, followed by nucleus growth and phase transformation to apatite. The present $a b$ initio calculations cannot provide information on which $\mathrm{CaP}$ phase is nucleated, so we assume that the $\mathrm{CaP}$ nucleus is amorphous. Magnesium inhibits nucleation by adsorbing faster than calcium, as an outer-sphere surface complex, at the active site.
\end{abstract}

INTRODUCTION

Biogeochemistry is defined here to encompass environmental geochemistry, biomineralization and geomedicine. The field has a profound, albeit largely unnoticed, impact on issues of importance to the general public. To increase the awareness and understanding of biogeochemistry, it is important to stress that universal physicochemical principles fundamentally control the complex interactions of solutions, biomolecules and minerals in the apparently unrelated realms of the human body and the natural geological environment (Sahai, 2002, 2003a; Anseau and others, 2005). In both realms, the systems under consideration may have chemical components that are similar and molecular conformations that are critical to understanding specific reaction pathways. An example is provided by the universal principles underlying the nucleation of the calcium phosphate mineral, apatite, as bones and teeth and as marine phosphorite deposits. Specifically, I consider the molecular-level interaction involved in heterogeneous, epitaxial apatite nucleation at inorganic surfaces (silicate bioceramic and diatomaceous opaline silica) and at organic (protein) surfaces. Crystallographic constraints help to determine the structure of the active, nucleating, surface site. A comparison of experimental ${ }^{31} \mathrm{P}$ NMR data obtained for bone with ${ }^{31} \mathrm{P}$ NMR data calculated for hypothetical molecular species will provide constraints for one possible reaction mechanism. The results are important to the field of bone biomineralization and contribute to understanding the formation of marine phosphorite deposits. A comparable methodology constructed for other chemical systems could provide similar, fundamental information for future biogeochemical investigations. 
MOTIVATION

\section{Background Information}

Biological apatite occurs in carbonated and fluorinated forms as dahllite and francollite, in our bones and teeth. Bone is a composite material consisting largely of nanocrystalline dahllite, framework proteins such as collagen, and acidic proteins such as bone sialoprotein (BSP) and osteopontin (OPN). Calcium phosphate (CaP) precipitation probably occurs extracellularly. It is hypothesized that nucleation begins at specific bone-mineralizing sites in spaces called "holes" created by the collagen scaffolding. The initial CaP phase formed has proven difficult to characterize. Subsequent transformations result in nanocrystalline apatite as the bone matures.

Calcium phosphate nucleation and crystal growth are probably promoted and modulated by phosphoproteins such as BSP and OPN (reviewed in Glimcher, 1998; Veis, 2003). BSP has seven sites containing phosphorylated serine in the peptide sequence S(P)EE (Salih and Flückiger, 2004), where phosphoserine is represented as $\mathrm{S}(\mathrm{P})$ or ser-P and $\mathrm{E}$ refers to the glutamic acid residue. These sites could, potentially, be involved in CaP nucleation. The role of BSP and/or phosphorylated residues versus alternative proteins/amino acid sequences is, currently, a hotly debated topic in the bone-growth literature. For example, an alternative scheme involving eight glutamic acid residues on BSP, but not the phosphorylated amino-acid residues, has been suggested as constituting a potential nucleating site for CaP (Hunter and Goldberg, 1994; Tye and others, 2003).

The mineral phase in bone changes from the earliest formed CaP phase to apatite as the bone matures in the vertebrate organism. Therefore, a study of bone at different stages of maturity should provide an indication of the pathway by which CaP nucleate, grows and transforms to apatite. In an experimental ${ }^{31} \mathrm{P}$ NMR study of bone at different stages of maturity, a change in an empirically-defined ${ }^{31} \mathrm{P}$ NMR parameter (the sign of "ı", defined in the ${ }^{31} P$ NMR Shift Calculations below) was observed in bone harvested from a few-days-old chick embryo to a several-weeks-old chicken (Wu and others, 2003). Intriguingly, a similar change was noted in vitro in going from phosphorylated proteins to the calcium-salts of the same proteins. It was suggested that the change in the sign of the " $\mathrm{"} \mathrm{NMR} \mathrm{parameter} \mathrm{is} \mathrm{indicative} \mathrm{of} \mathrm{calcium} \mathrm{association} \mathrm{with} \mathrm{phosphory-}$ lated proteins. Further, the similar behavior of phosphorylated proteins and maturing bone was suggested to indicate that calcium binding at phosphorylated amino acid sites, as in BSP, could play a vital role in catalyzing CaP nucleation (Wu and others, 2003). The structure of the active nucleating site, however, was not proposed previously. In the present study, it will be assumed that a potential nucleating site in BSP consists of the $\mathrm{S}(\mathrm{P}) \mathrm{EE}$ sequence. The structure (geometry) of this site will be investigated here.

In a related phenomenon, apatite growth is promoted on silicate bioceramic surfaces in vivo when implanted in model test animals and in vitro when immersed in simulated body fluid that has the composition of human blood serum. The rates of bonding between silicate bioceramic implants and existing bone or tooth are faster than on other types of traditional implants. Silicate bioceramics are used, therefore, in orthopedic and dental prosthetic implants (Hench, 1998). A remarkably similar phenomenon may also be occurring in the formation of apatite in marine phosphorite deposits. In the case of phosphorite deposits, authigenic apatite is precipitated in relatively shallow marine sediments during early diagenesis. The precipitates are often overgrowths on diatomaceous earths made up of amorphous, opaline silica (see for example, the photomicrographs in Baturin, 2000). Moreover, magnesium, a major ion in natural solutions such as seawater and blood, is known to inhibit inorganic and biological apatite precipitation. The inhibitory effect may be related to the poisoning of surface nucleation sites by magnesium and the slow dehydration kinetics of sorbed magnesium (Sahai, 2003b). Thus, analogous reactions may occur in the apparently 
diverse realms of marine pore-fluids and human blood plasma. Clearly, it is critical to understand the reaction mechanisms involved in the earliest stages of $\mathrm{CaP}$ nucleation on protein and bioceramic surfaces, in order to design targeted treatments for osteoporosis, osteomalacia, bone-fractures, and for rapid recovery from artificial joint replacement and dental surgeries. Equally important from the geochemical perspective is the molecular-level understanding of phosphorite deposit formation.

\section{Objectives and Conceptual Approach}

The objectives of this work are to obtain a reaction pathway for CaP nucleation consistent with the experimental ${ }^{31} \mathrm{P}$ NMR data on bone, to obtain the geometry of the hypothesized active site on BSP, to show that common mechanisms also operate in bone growth at bioceramic surfaces and in marine phosphorite growth on diatomaceous, opaline silica substrates, and to examine the role of magnesium in inhibiting CaP nucleation.

To identify the geometry of the active site, the tack taken is to use crystal structure arguments in conjunction with the analogy to silicate bioceramics. The structure of the active site on silicate bioceramics is known and will be modeled directly. The protein structure for BSP is unknown. A model compound will therefore be used to represent the proposed active site, $\mathrm{S}(\mathrm{P}) \mathrm{EE}$. The model compound chosen is the Ca-salt of o-phosphoserine, $\mathrm{CaC}_{3} \mathrm{H}_{6} \mathrm{O}_{6} \mathrm{NP}\left(\mathrm{H}_{2} \mathrm{O}\right)$. This compound has several advantages. First, its x-ray crystal structure is known (fig. 1) (Suga and Okabe, 1996). Second, phosphoserine is present in the $\mathrm{S}(\mathrm{P}) \mathrm{EE}$ amino-acid residue of the proposed active active. Further, the Ca-salt of phosphoserine was used previously as an analog of phosphorylated proteins in bone in an experimental ${ }^{31} \mathrm{P}$ NMR study (Wu and others, 2003). A major difference exists, however, between the model compound and the actual protein. In BSP, the amino acid residues would be connected by peptide bonds, whereas the serine molecules in the model compound are not connected to each other. Nonetheless, the carboxylate and phosphorylate groups of the model fragment can be considered as comprising the $\mathrm{S}(\mathrm{P})$ and $\mathrm{E}$ residues of the peptide in the actual active site. Also shown in figure 1 is the crystal structure of apatite, the final mineral phase in mature bone.

To elucidate the reaction steps involved in the apatite nucleation mechanism, ${ }^{31} \mathrm{P}$ NMR shifts and the " $\iota$ " parameter are calculated for model compounds using $a b$ initio molecular orbital (MO) theory. Results are compared with experimentally obtained data for bone. Similar changes in the ${ }^{31} \mathrm{P}$ NMR parameters of model structures and actual bone at various stages of maturation would suggest that the selected model structures are consistent with reaction intermediates in the proposed pathway. The inhibitory effect of magnesium on apatite nucleation is studied by comparing minimum-energy structures for calcium and magnesium phosphate formation on silicate bioceramic substrates.

\section{METHODS}

\section{Geometry Optimizations}

Calculations were performed at the ab initio Hartree-Fock (HF) level using the quantum chemistry software packages, Gaussian 98 (Frisch and others, 1998) and GAMESS (Schmidt and others, 1993). Effective core potentials and valence double zeta basis sets (Stevens and others, 1992) in GAMESS were employed for complete optimizations of the silicate bioceramic structures (Sahai and Tossell, 2000; Sahai, 2003b). The split-valence 3-21G* basis set (Hehre and others, 1986) in Gaussian 98 was used for constrained geometry optimizations of the phosphoserine molecules.

The starting molecule was a phosphorylated serine as a model for the proposed active site consisting of $\mathrm{S}(\mathrm{P}) \mathrm{EE}$. The cartesian coordinates of $\mathrm{C}, \mathrm{N}, \mathrm{O}$ and $\mathrm{P}$ atoms for the molecule were extracted from the X-Ray Diffraction (XRD) crystal structure of a 


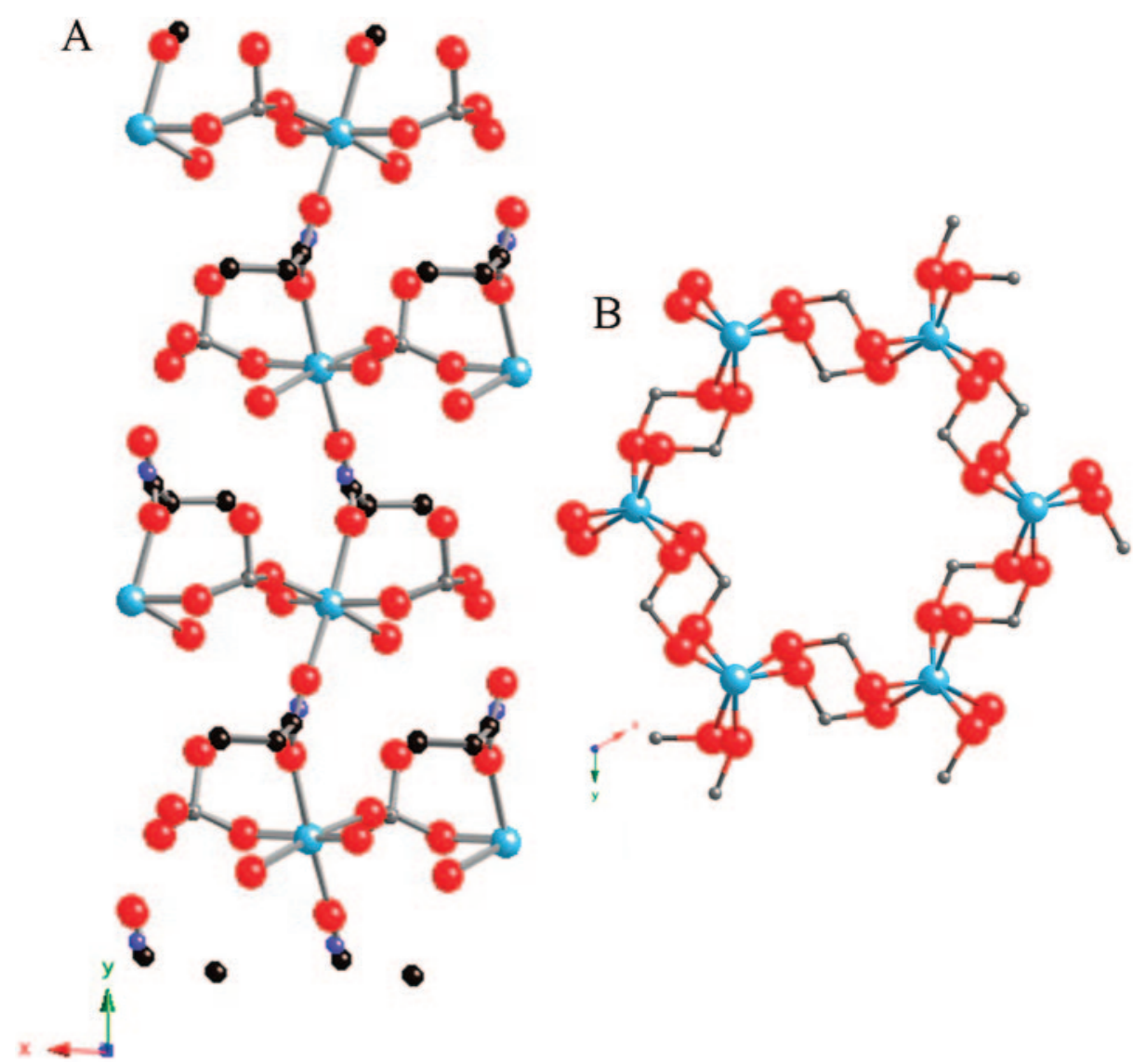

Fig. 1. Representation of the crystal structures of (A) the Ca-salt of o-phosphoserine, and (B) apatite. Plan view of the (001) face is shown for each crystal. The Ca-salt of phosphoserine serves as a model for the $\mathrm{S}(\mathrm{P}) \mathrm{EE}$ site in BSP. A caveat is that the serine molecules in the model compound are not connected to each other as the amino-acid residues would be through peptide bonds in the real S(P)EE site in BSP. Also, the apatite crystal shown is fluorapatite. Hydroxide ions would substitute for fluorides in hydroxyapatite. Legend for atoms: C, black; N, dark blue; O, red; P, gray; F, green; Ca, light blue; $\mathrm{H}$ atom positions not shown. Structures are drawn using software CrystalMaker@ (Palmer, 2004).

calcium salt of o-phosphoserine, and "frozen" at the crystal structure. H atoms were added to complete the coordination of $\mathrm{C}$ and $\mathrm{N}$ atoms, and only $\mathrm{H}$ atom positions were optimized at the HF/3-21G* level. Thus, a constrained (partial) geometry optimization was performed for the phosphorylated serine molecule (fig. 2A). Subsequently, model molecules were created to represent calcium sorption at the starting active site, phosphate attachment to the calcium resulting in the critical CaP nucleus, and further attachment of calcium and phosphate to the model CaP nucleus in order to represent growth. Different levels of protonation of the phosphate moiety were considered.

\section{${ }^{31}$ P NMR Shift Calculations}

${ }^{31} \mathrm{P}$ NMR shifts were calculated at the final geometry for each molecule. The effects of basis size and computational level (Hartree-Fock versus B3LYP) have been considered in detail for ${ }^{31} \mathrm{P}$ NMR (Alam, 1998, 1999). Accordingly, isotropic and anisotropic chemical shifts were calculated using the HF/6-311+G(2d,p) level consistent with the GIAO method (Wolinski and others, 1992) as implemented in Gaussian 98. 
A

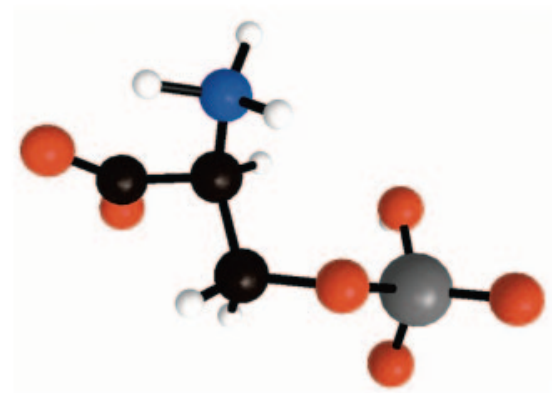

$\mathrm{C}$

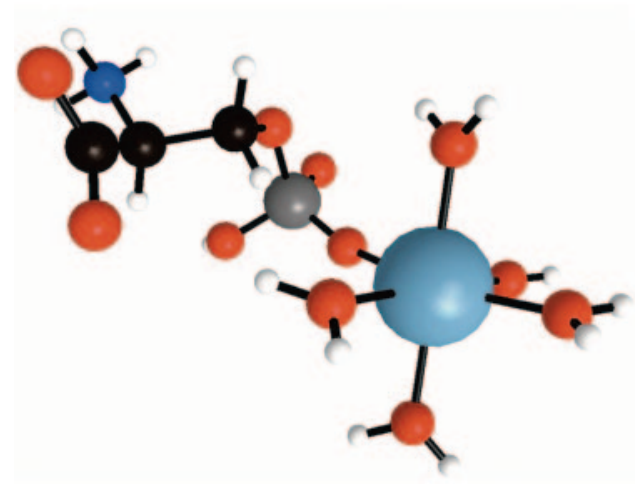

B

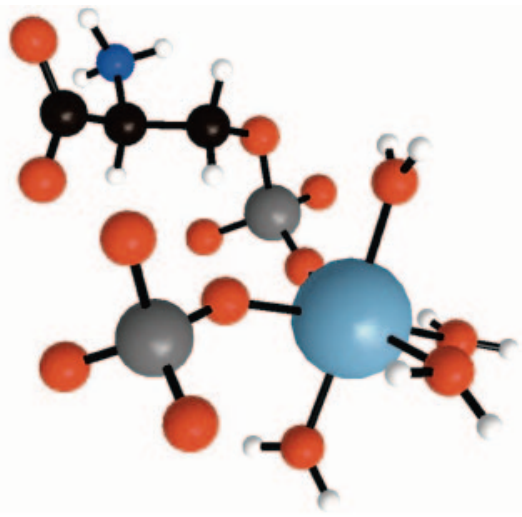

$\mathrm{D}$

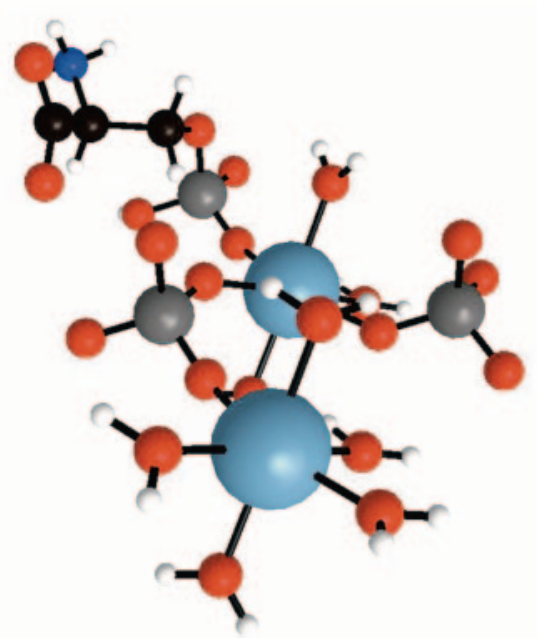

Fig. 2. Partially constrained geometry optimizations of (A) ser- $(\mathrm{H}) \mathrm{PO}_{4}$ representing a portion of the active site (B) Ser- $(\mathrm{H}) \mathrm{PO}_{4}-\mathrm{Ca}\left(\mathrm{H}_{2} \mathrm{O}\right)_{5}$ representing calcium sorption (C) ser- $\mathrm{HPO}_{4}-\mathrm{Ca}\left(\mathrm{H}_{2} \mathrm{O}\right)_{4}\left(\mathrm{PO}_{4}\right)^{2-}$ representing phosphate attachment resulting in the critical nucleus, and (D) ser- $\mathrm{HPO}_{4^{-}}$ $\mathrm{Ca}\left(\mathrm{H}_{2} \mathrm{O}\right)_{3}\left(\mathrm{PO}_{4}\right)(\mathrm{Ca})\left(\mathrm{H}_{2} \mathrm{O}\right)_{5}\left(\mathrm{PO}_{4}\right)^{3-}$ representing growth after nucleation. See text for details.

It is computationally difficult to obtain accurate absolute shielding values for the ${ }^{31} \mathrm{P}$ standard (an $85 \mathrm{wt} \% \mathrm{H}_{3} \mathrm{PO}_{4}$ solution), due to problems associated with modeling $\mathrm{H}$-bonding and with representing the different protonation levels of phosphoric acid in solution. Absolute shieldings are reported therefore instead of shifts. Useful information is also contained in the operationally defined "sideband pattern index" (Wu and others, 2003):

$$
\mathrm{\iota}_{\text {calc }} \equiv \sigma_{22, \text { calc }}-\sigma_{\text {iso,calc }}=\delta_{\text {iso,expt }}-\delta_{22, \text { expt }}
$$

where $\sigma_{\text {iso }}, \sigma_{11}, \sigma_{22}$, and $\sigma_{33}$ are the isotropic absolute shielding and the eigenvalues of the shielding tensor, and $\delta_{\text {iso, }} \delta_{11}, \delta_{22}$ and $\delta_{33}$ are the isotropic absolute shift and the eigenvalues of the shift tensor.

The " $\iota$ " parameter is related to the skew of the chemical shift tensor (Mason, 1993; $\mathrm{Wu}$ and others, 2003). This empirically defined parameter tells about the symmetry of the powder pattern, not of the physical bonding environment in the crystal. A positive sign for $\iota$ implies that the intensity of the first upfield sideband (more negative shift or more positive shielding) is greater than that of the first downfield sideband in the 
spectrum. For several phosphoproteins examined, it was found empirically that the sign of $\iota$ changes from negative to positive, respectively, in the absence and presence of calcium ions. A positive sign of $\iota$ may then be taken to indicate calcium association with phosphorylated sites, and thus, with CaP nucleation.

RESULTS

\section{Geometry Optimizations}

The phosphoserine molecule was extracted and optimized from the crystal structure (fig. 2A). Next, the Ca-bound phosphorylated serine (fig. 2B) was optimized, representing the first step in nucleation of the CaP phase. Excluding the phosphoryl of the starting Ser-P, each Ca is bonded to five other oxygens. Addition of an inorganic phosphate resulted in the CaP critical nucleus modeled as Ser- $\mathrm{PO}_{4}-\mathrm{Ca}-\mathrm{PO}_{4}$ (fig. 2C). Increasing the number of $\mathrm{Ca}$ and phosphate moeities represents growth of the critical nucleus to Ser- $\mathrm{PO}_{4}$-Ca- $\left(\mathrm{PO}_{4}\right)_{2} \mathrm{Ca}$ (fig. 2D).

At the physiological $\mathrm{pH}=7.2, \mathrm{HPO}_{4}^{2-}$ and $\mathrm{H}_{2} \mathrm{PO}_{4}^{-}$are the dominant forms of phosphate, but apatite contains the $\mathrm{PO}_{4}^{3-}$ anion. Previous work has suggested that the earliest calcium phosphate phase in bone may be protonated (Rey and others, 1991a, 1991b). In our calculations, therefore, different protonation levels of $\mathrm{PO}_{4}$ were considered (table 1). Type 1 molecules are those where all the phosphate groups are deprotonated, Ser-PO $\mathrm{P}_{4}$ or Ser-P. Molecules where only the phosphoserines are protonated, serine- $\mathrm{HPO}_{4}$ or Ser- $(\mathrm{H}) \mathrm{P}$, are denoted Type 2 molecules. Finally, for type 3 molecules, all the phosphate groups are protonated. For type 2 and type 3 molecules, we started with the (constrained) optimized Type 1 structures, added $\mathrm{H}$ atom(s) to the $\mathrm{PO}_{4}$ group on the first serine molecule, and optimized the position of the $\mathrm{H}$ atom(s).

\section{${ }^{31} P$ NMR Properties}

Calculated ${ }^{31} \mathrm{P}$ absolute $\sigma_{\text {iso }}$ and $\iota$ are reported in table 1 . The sign of $\iota$ predicted for $\mathrm{PO}_{4}$ groups are positive (with two exceptions) in all type 1 molecules. Attachment of Ca to the phosphate group (molecule $1 \mathrm{~b}$ ) and formation of the CaP critical nucleus (molecule 1c) do not change the negative sign of $\iota$.

For type 2 molecules containing $\mathrm{HPO}_{4}$ groups, ı has a negative sign (with one exception). On Ca binding, formation of the CaP critical nucleus and further growth the sign of $\iota$ remains negative (molecules $2 \mathrm{a}$ to $2 \mathrm{~d}$ ). A consistent trend is not preserved for type 3 molecules.

\section{DISCUSSION}

\section{Initial Steps in Calcium Phosphate Nucleation and Growth}

A growing body of direct and indirect evidence supports the hypothesis that phosphorylated proteins promote CaP nucleation. First, phosphoproteins are the only organic components present in all normally and pathologically calcified tissues (Glimcher, 1984, 1989). Radiolabeling experiments using ${ }^{33} \mathrm{P}_{\mathrm{i}}$ (inorganic phosphate) have shown that phosphoproteins are synthesized by osteoblasts themselves not in some other tissue followed by transport to the bone-forming site, supporting the notion that phosphoproteins promote nucleation (Landis and others, 1984). The lag time (induction period) between immersion of a protein in supersaturated solution and the onset of nucleation is an inverse measure of the catalytic efficiency of the protein. Significantly, experiments measuring the induction period suggest that demineralized collagen containing phosphorylated residues is more effective at catalyzing nucleation than enzymatically dephosphorylated collagen (Endo and Glimcher, 1986). It has also been shown that calcium sorbed on Ser-P and Thr-P (phosphothreonine) is capable of further binding with $\mathrm{P}_{\mathrm{i}}$, presumably through the formation of ternary complexes, indicated here by Ser-PO $-\mathrm{Ca}-\mathrm{P}_{\mathrm{i}}$, thus providing at least the minimum CaP unit required for nucleation (Lee and others, 1983). Also, the concentration of Ser-P is 


\section{TABLE 1}

${ }^{31} \mathrm{P}$ NMR isotropic shieldings and $\mathrm{\iota}$ values (in ppm) at the HF/6-311+G(2d, p) level. Average values are denoted in \langle\rangle . Note increasing number of calcium and phosphate ions down the column for each molecule type

\begin{tabular}{|c|c|c|c|}
\hline Molecule & $\mathrm{PO}_{4}$ type & $\sigma_{\text {iso }}$ & $\mathbf{l}$ \\
\hline \multicolumn{4}{|l|}{ Type 1 ( $\mathrm{PO}_{4}$ on serine $)$} \\
\hline a. ser- $\mathrm{PO}_{4}{ }^{2-}$ & Ser-P & 343.5 & 32.1 \\
\hline b. ser- $\mathrm{PO}_{4}-\mathrm{Ca}\left(\mathrm{H}_{2} \mathrm{O}\right)_{5}{ }^{0}$ & Ser-P & 344.4 & 4.5 \\
\hline c. ser- $-\mathrm{PO}_{4}-\mathrm{Ca}\left(\mathrm{H}_{2} \mathrm{O}\right)_{4}\left(\mathrm{PO}_{4}\right)^{3-}$ & $\begin{array}{l}\text { Ser-P } \\
\text { Ca-P }\end{array}$ & $\begin{array}{l}345.8 \\
353.8\end{array}$ & $\begin{array}{c}19.8 \\
11.1 \\
<15.5>\end{array}$ \\
\hline d. ser- $\mathrm{PO}_{4} \mathrm{Ca}\left(\mathrm{H}_{2} \mathrm{O}\right)_{3}\left(\mathrm{PO}_{4}\right)(\mathrm{Ca})\left(\mathrm{H}_{2} \mathrm{O}\right)_{5}\left(\mathrm{PO}_{4}\right)^{4-}$ & $\begin{array}{l}\text { Ser-P } \\
\text { Ca-P } \\
\text { Ca-P }\end{array}$ & $\begin{array}{l}345.8 \\
339.2 \\
443.7\end{array}$ & $\begin{array}{c}+28.5 \\
-5.7 \\
-67.0 \\
<-14.7>\end{array}$ \\
\hline \multicolumn{4}{|l|}{ Type $2\left(\mathrm{HPO}_{4}\right.$ on serine $)$} \\
\hline a. ser- $\mathrm{HPO}_{4}^{-}$ & Ser-(H)P & 344.5 & -23.1 \\
\hline b. ser- $\mathrm{HPO}_{4}-\mathrm{Ca}\left(\mathrm{H}_{2} \mathrm{O}\right)_{5}^{+}$ & Ser-(H)P & 350.1 & -21.6 \\
\hline c. ser- $\mathrm{HPO}_{4}-\mathrm{Ca}\left(\mathrm{H}_{2} \mathrm{O}\right)_{4}\left(\mathrm{PO}_{4}\right)^{2-}$ & $\begin{array}{l}\text { Ser-(H)P } \\
\text { Ca-P }\end{array}$ & $\begin{array}{l}350.1 \\
342.0\end{array}$ & $\begin{array}{c}-12.2 \\
-6.8 \\
<-9.5>\end{array}$ \\
\hline d. ser- $\mathrm{HPO}_{4} \mathrm{Ca}\left(\mathrm{H}_{2} \mathrm{O}\right)_{3}\left(\mathrm{PO}_{4}\right)(\mathrm{Ca})\left(\mathrm{H}_{2} \mathrm{O}\right)_{5}\left(\mathrm{PO}_{4}\right)^{3-}$ & $\begin{array}{l}\text { Ser-(H)P } \\
\text { Ca-P-Ca } \\
\text { Ca-P }\end{array}$ & $\begin{array}{l}349.6 \\
342.2 \\
347.2\end{array}$ & $\begin{array}{c}-13.9 \\
-8.2 \\
1.9 \\
<-6.7>\end{array}$ \\
\hline \multicolumn{4}{|l|}{ Type $3\left(\mathrm{HPO}_{4}\right.$ on all phosphates) } \\
\hline a. ser- $\mathrm{HPO}_{4}^{-}$ & Ser-(H)P & 344.5 & -23.1 \\
\hline b. ser- $\mathrm{HPO}_{4}-\mathrm{Ca}\left(\mathrm{H}_{2} \mathrm{O}\right)_{5}^{+}$ & Ser-(H)P & 350.1 & -21.6 \\
\hline c. ser- $\mathrm{HPO}_{4}-\mathrm{Ca}\left(\mathrm{H}_{2} \mathrm{O}\right)_{4}\left(\mathrm{HPO}_{4}\right)^{-}$ & $\begin{array}{l}\text { Ser-(H)P } \\
\mathrm{Ca}-(\mathrm{H}) \mathrm{P}\end{array}$ & $\begin{array}{l}349.7 \\
346.3\end{array}$ & $\begin{array}{l}-17.9 \\
+19.5 \\
\langle+0.8\rangle\end{array}$ \\
\hline d. ser- $\mathrm{HPO}_{4} \mathrm{Ca}\left(\mathrm{H}_{2} \mathrm{O}\right)_{3}\left(\mathrm{HPO}_{4}\right)(\mathrm{Ca})\left(\mathrm{H}_{2} \mathrm{O}\right)_{5}\left(\mathrm{HPO}_{4}\right)^{-}$ & $\begin{array}{l}\text { Ser-(H)P } \\
\mathrm{Ca}-(\mathrm{H}) \mathrm{P} \\
\mathrm{Ca}-(\mathrm{H}) \mathrm{P}\end{array}$ & $\begin{array}{l}291.5 \\
448.0 \\
330.4\end{array}$ & $\begin{array}{l}+19.5 \\
+15.3 \\
-24.4 \\
\langle+3.5\rangle\end{array}$ \\
\hline
\end{tabular}

much higher in the earliest formed bones than in later stages of bone-formation, suggesting the involvement of Ser-P in nucleation (Lian and others, 1982). Moreover, ${ }^{31} \mathrm{P}$ anisotropic shifts measured by Differential Cross Polarization MAS NMR for bone from 10-day old chick embryo is similar to that obtained for calcium-complexed Thr-P and demineralized phosvitin (Wu and others, 2000).

In experimental ${ }^{31} \mathrm{P}$ NMR studies of phosphoproteins, a reversal in the sign of $\iota$ was noted from negative to positive as bone matures ( $\mathrm{Wu}$ and others, 2003). This result suggests that a similar sign change should be seen as a CaP phase nucleates, grows, and transforms to apatite. A complete reversal in sign of $\iota$ from negative to positive is produced 
in the present model structures going from molecule $2 \mathrm{a} \rightarrow 2 \mathrm{~b} \rightarrow 3 \mathrm{c} \rightarrow 3 \mathrm{~d}$. This sequence corresponds to a pathway involving the following species: ser- $\mathrm{HPO}_{4}^{-} \rightarrow$ ser- $\mathrm{HPO}_{4-}$ $\mathrm{Ca}\left(\mathrm{H}_{2} \mathrm{O}\right)_{5}^{+} \rightarrow$ ser- $\mathrm{HPO}_{4}-\mathrm{Ca}\left(\mathrm{H}_{2} \mathrm{O}\right)_{4}\left(\mathrm{HPO}_{4}\right)^{-} \rightarrow \operatorname{ser}-\mathrm{HPO}_{4} \mathrm{Ca}\left(\mathrm{H}_{2} \mathrm{O}\right)_{3}\left(\mathrm{HPO}_{4}\right)(\mathrm{Ca})$ $\left(\mathrm{H}_{2} \mathrm{O}\right)_{5}\left(\mathrm{HPO}_{4}\right)^{-}$. The pathway represents $\mathrm{Ca}^{2+}$ and $\mathrm{HPO}_{4}^{2-}$ sorption at the active site, $\mathrm{CaP}$ nucleation and nucleus growth. Subsequent deprotonation of molecule $3 \mathrm{~d}$ to $1 \mathrm{~d}$, that is, ser- $\mathrm{HPO}_{4} \mathrm{Ca}\left(\mathrm{H}_{2} \mathrm{O}\right)_{3}\left(\mathrm{HPO}_{4}\right)(\mathrm{Ca})\left(\mathrm{H}_{2} \mathrm{O}\right)_{5}\left(\mathrm{HPO}_{4}\right)^{-} \rightarrow \operatorname{ser}-\mathrm{PO}_{4} \mathrm{Ca}\left(\mathrm{H}_{2} \mathrm{O}\right)_{3}\left(\mathrm{PO}_{4}\right)(\mathrm{Ca})$ $\left(\mathrm{H}_{2} \mathrm{O}\right)_{5}\left(\mathrm{PO}_{4}\right)^{4-}$, results in the sign of $\iota$ becoming negative again. This last change is not observed in the experimental system, where the positive value of $\iota$ is maintained as bone matures. One possible interpretation is that the growing $\mathrm{CaHPO}_{4}$ precursor phase molecule 3d, ser- $\mathrm{HPO}_{4} \mathrm{Ca}\left(\mathrm{H}_{2} \mathrm{O}\right)_{3}\left(\mathrm{HPO}_{4}\right)(\mathrm{Ca})\left(\mathrm{H}_{2} \mathrm{O}\right)_{5}\left(\mathrm{HPO}_{4}\right)^{-}$does not completely deprotonate prior to phase transformation. Rather, the precursor $\mathrm{CaP}$ phase may transform to apatite while still partially protonated, consistent with FTIR measurements on early bone (Rey and others, 1991a, 1991b). Thus, the experimentally observed change in the sign of $\iota$ as bone ages is related to stages involving $\mathrm{CaP}$ nucleus growth and phase transformation.

Note that the current approach indicates only one possible pathway that is consistent with the observed NMR data. The computational approach here does not tell us if this is a unique pathway and cannot tell us which calcium phosphate phase forms the critical nucleus. The critical nucleus is modeled as $\mathrm{CaP}$ and is assumed to be an amorphous phase. Finally, note that in our model structures, the critical nucleus consists of one $\mathrm{CaP}$ unit and growth is represented by the addition of an additional $\mathrm{CaP}$ unit. The actual critical nucleus, however, must be at least two $\mathrm{CaPO}_{4}$ units large and growth of the nucleus means an even bigger size (Sahai and Tossell, 2000).

\section{Structure of the Nucleating Site on BSP}

The conformation and structure of neither whole BSP nor of the S(P)EE peptide sequence are currently available. This precludes using the protein structure directly for determining the structure of the hypothesized active site. I resorted, therefore, to using the Ca-salt of phosphoserine as a model compound. A fragment of this compound is shown in figure $3 \mathrm{~A}$ where the calcium ion is bonded to two phosphoserine molecules through the carboxylate groups, four phosphoserine molecules through the phosphoryl groups and one water molecule. The carboxylate and phosphorylate groups in the model fragment represent the glutamate or aspartate and the phosphorylate residues of the $\mathrm{S}(\mathrm{P}) \mathrm{EE}$ sequence. Also shown is a fragment of the apatite crystal structure where the calcium ion is bonded to five $\mathrm{PO}_{4}$ groups and one $\mathrm{OH}$ group (fig. 3B). In both fragments, the angle between the oxygen atoms of any three adjacent acidic groups surrounding calcium is $60^{\circ}$. Further, the distance between the oxygen atoms in the upper and lower triangles is approximately 3.4 to $3.5 \AA$. Thus, the calcium ion is held in a cavity of negative charge formed by three acidic groups (carboxylates and phosphorylates in the model compound, $\mathrm{S}(\mathrm{P}) \mathrm{EE}$ in $\mathrm{BSP}, \mathrm{PO}_{4}, \mathrm{OH}$ in apatite) arranged in an equilateral triangle.

\section{Analogy With CaP Nucleation at Silica Bioceramic Surfaces and With Nodular Phosphorite Precipitation in Marine Sediments}

In a previous study, we used MO calculations to identify the surface site that is responsible for nucleation of the initial CaP nucleus on amorphous silica surfaces, and to determine the elementary reaction steps involved (Sahai and Tossell, 2000). The calculations predicted that only a specific structure, the silicate three-ring $\left(\mathrm{Si}_{3} \mathrm{O}_{6} \mathrm{H}_{6}\right)$ or cyclic trimer (fig. 3C), was capable of nucleating the $\mathrm{CaP}$ nucleus with ${ }^{31} \mathrm{P}$ and IR/Raman vibrational properties similar to the earliest mineral-phase in bone (note that in this model structure, silicon is bonded to $\mathrm{H}$ only to terminate the model structure as is routinely done in ab initio models. In the real system, the silicon atoms would be bonded to oxygen atoms). The reaction intermediates predicted for CaP nucleation on silica bioceramic are $\mathrm{Si}_{3} \mathrm{O}_{6} \mathrm{H}_{6}\left(\mathrm{H}_{2} \mathrm{O}\right)_{3} \rightarrow \mathrm{Si}_{3} \mathrm{O}_{6} \mathrm{H}_{6} \mathrm{Ca}\left(\mathrm{H}_{2} \mathrm{O}\right)_{6}^{2+}$ where 

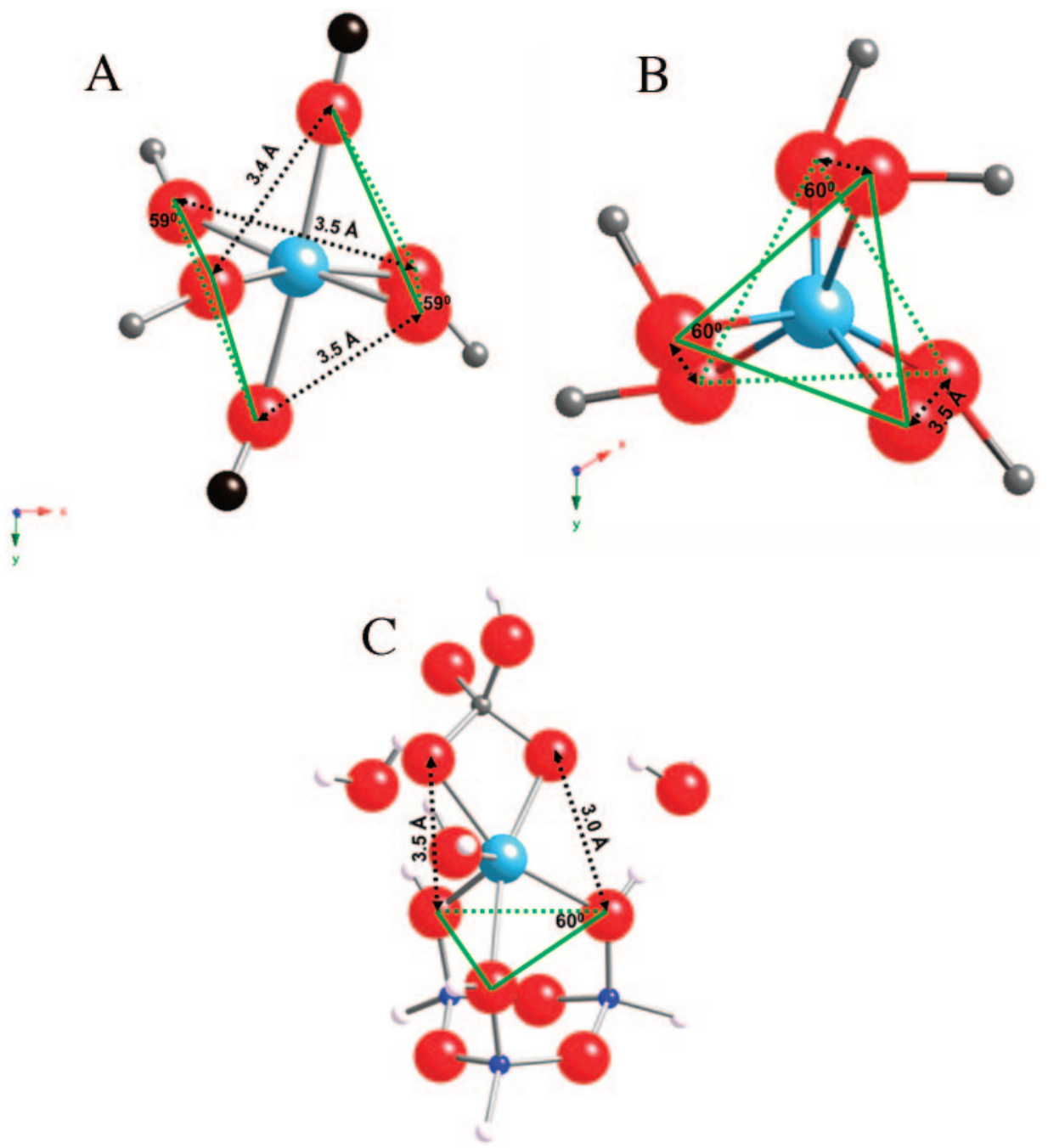

Fig. 3. Molecular fragments extracted from the crystal structure of (A) Ca-salt of O-phosphoserine, where most $\mathrm{H}, \mathrm{C}, \mathrm{N}$, and $\mathrm{O}$ atoms of serine have been removed for clarity, except for the $\mathrm{C}$ and $\mathrm{P}$ atoms belonging to the carboxylate and phosphorylate groups, and (B) apatite where oxygen atoms of the phosphate groups have been removed for clarity. Also shown is $(\mathrm{C})$ the calculated CaP nucleus on the silica three ring, $\mathrm{Si}_{3} \mathrm{O}_{6} \mathrm{H}_{6} \mathrm{CaHPO}_{4}\left(\mathrm{H}_{2} \mathrm{O}\right)_{3}$ (Sahai and Tossell, 2000) obtained using the quantum chemistry software package, GAMESS (Schmidt and others, 1993). The oxygen atoms of the acidic phosphoryl and/or carboxyl groups (A, B), and the silanol groups in (C) form a triangular cavity that are proposed to constitute the active site. Note the $60^{\circ}$ angles between oxygen atoms of acidic or silanol groups within each triangular cavity, and the $\sim 3.4$ to $3.5 \AA$ distances between oxygen atoms of the acidic/silanol groups above and below the calcium ion. Structures are drawn using software CrystalMaker 6.3.5 (Palmer, 2004). Legend for atoms: $\mathrm{H}$, white; $\mathrm{C}$, black; $\mathrm{O}$, red; $\mathrm{Si}$, dark blue; $\mathrm{P}$, gray; Ca, light blue.

$\mathrm{Ca}^{2+}$ is adsorbed as an inner-sphere surface complex $\rightarrow \mathrm{Si}_{3} \mathrm{O}_{6} \mathrm{H}_{6} \mathrm{CaHPO}_{4}\left(\mathrm{H}_{2} \mathrm{O}\right)_{3}$, which represents the earliest $\mathrm{CaP}$ nucleus (Sahai and Tossell, 2000).

The intriguing result is that the surface silanol sites ( $\mathrm{SiOH}$ functional groups) are arranged at $60^{\circ}$ from each other in the three-ring. This allows the calcium ion to bond to the oxygens of the silanol sites in a geometry similar to that found in the Ca-salt of o-phosphoserine and in apatite. Equally important, another ring structure, the silicate four-ring $\left(\mathrm{Si}_{4} \mathrm{O}_{8} \mathrm{H}_{8}\right)$ or cyclic tetramer is incapable of producing the bone-like $\mathrm{CaHPO}_{4}$ 
nucleus (Sahai and Tossell, 2000). The tetramer has a different geometrical arrangement of atoms with silanols at $90^{\circ}$ from each other. These results are of great significance, because they suggest that a specific geometry is required for nucleation, that the geometry identified here provides a stereochemical match for nucleation, and that the process of $\mathrm{CaP}$ nucleation on silica is analogous to the mechanism for apatite nucleation on proteins associated with bone. The formation of authigenic apatite on opaline, diatomaceous silica could also proceed through similar reaction intermediates, in cases where the apatite precipitates are formed as overgrowths on diatomaceous earths.

A consideration of the ${ }^{29} \mathrm{Si}$ NMR, IR, Raman and XRD data for a silica bioceramic reacting with simulated body fluid provides an estimate for the rate of the reaction. The adsorption of calcium and phosphate ions resulting in nucleation of the oligomer is the fastest step, occurring within minutes to $\sim 1$ hour resulting in the initial decrease then increase in ${ }^{29} \mathrm{Si}$ NMR shieldings. The hydrolysis of the Si three-ring, if it occurs, takes place within the first day $(\sim 24$ hours) of reaction with SBF. Finally, the aggregation of oligomers and transformation to apatite crystals sufficiently large to be detected by X-Ray Diffraction is the slowest step taking about 2 weeks.

\section{Effect of Magnesium on Nucleation and Crystal Growth}

Magnesium plays a complex role in apatite precipitation. First, magnesium kinetically inhibits apatite nucleation and crystal growth. Second, the large total dissolved $\mathrm{Mg}$ to $\mathrm{Ca}\left(\mathrm{Mg}_{\mathrm{T}} / \mathrm{Ca}_{\mathrm{T}}\right)$ ratio of seawater and blood adds a thermodynamic advantage to magnesium in suppressing apatite formation (for example, Van Cappellen, ms, 1991). It is thus quite remarkable that apatite precipitates from such solutions. Extraordinary geochemical conditions and processes have therefore been suggested in the literature to produce the special solutions for authigenic apatite precipitation.

The effect of $\mathrm{Mg}^{2+}$ on Ca nucleation at silica surfaces has been considered using ab initio methods (Sahai, 2003b). The rate at which the hexaquo $\mathrm{Mg}^{2+}$ cation forms a surface-complex, decreases as $\mathrm{Mg}^{2+}$ outer-sphere $>\mathrm{Mg}^{2+}$ inner-sphere $>\mathrm{Ca}^{2+}$ inner-sphere. This result and its consequences for $\mathrm{CaP}$ nucleation can be rationalized as follows. The greater gas-phase charge-to-radius ratio of $\mathrm{Mg}^{2+}$ compared to $\mathrm{Ca}^{2+}$ provides greater electrostatic attraction to the surface silanol sites, thus, driving faster $\mathrm{Mg}^{2+}$ adsorption. $\mathrm{Mg}^{2+}$ sorbs rapidly, blocking access of $\mathrm{Ca}^{2+}$ to surface sites and inhibiting CaP nucleation.

The larger charge-to-radius ratio of $\mathrm{Mg}^{2+}$ than $\mathrm{Ca}^{2+}$ has another consequence. Solvating water molecules are more tightly bound to $\mathrm{Mg}\left(\mathrm{H}_{2} \mathrm{O}\right)_{6}^{2+}$ than to $\mathrm{Ca}\left(\mathrm{H}_{2} \mathrm{O}\right)_{6}^{2+}$, so the $\mathrm{Mg}^{2+}$ ion adsorbs initially as an outer-sphere complex. Calcium, on the other hand, forms the inner-sphere surface complex directly. $\mathrm{HPO}_{4}^{2-}$ can then attach simply to the Ca inner-sphere complex, forming the $\mathrm{Si}_{3} \mathrm{O}_{6} \mathrm{H}_{6} \mathrm{CaHPO}_{4}\left(\mathrm{H}_{2} \mathrm{O}\right)_{3}$ critical nucleus. Meanwhile, the outer-sphere $\mathrm{Mg}^{2+}$ surface complex has to convert to the inner-sphere complex for $\mathrm{HPO}_{4}^{2-}$ attachment to form the analogous $\mathrm{Si}_{3} \mathrm{O}_{6} \mathrm{H}_{6} \mathrm{MgHPO}_{4}\left(\mathrm{H}_{2} \mathrm{O}\right)_{3}$ nucleus. The net result is that $\mathrm{HPO}_{4}^{2-}$ attachment at sorbed $\mathrm{Ca}^{2+}$ is faster than at sorbed $\mathrm{Mg}^{2+}$. CaP nucleation is thus retarded, but not entirely prevented, from solutions with high $\mathrm{Mg} / \mathrm{Ca}$ ratios. The geochemical implication is that the $\mathrm{Mg} / \mathrm{Ca}$ ratio of pore-water does not need to be altered significantly from seawater composition by extraordinary ad hoc processes to permit authigenic apatite precipitation.

The composition of marine pore-water from which authigenic apatite is formed is close to average seawater. The $\mathrm{pH}$ is $\sim 7$ to 8 , ionic strength $\sim 0.6 \mathrm{M}$, total dissolved magnesium $\mathrm{Mg}_{\mathrm{T}} \sim 55 \mathrm{mM}$, total dissolved calcium $\mathrm{Ca}_{\mathrm{T}} \sim 15 \mathrm{mM}$, and total dissolved inorganic phosphorous $\mathrm{P}_{\mathrm{T}} \sim 20-100 \mathrm{mM}$ (Froelich and others, 1988; Van Cappellen, ms, 1991; Jarvis and others, 1994). Mammalian blood from which biological apatite precipitates, and marine pore-water have broadly similar major element compositions. These similarities support the idea that the elementary steps in the reaction pathway 
for heterogeneous inorganic apatite nucleation are very similar to that for biological apatite formation (Sahai, 2003b).

\section{SUMMARY}

The approach taken here provides one possible reaction pathway consistent with ${ }^{31} \mathrm{P}$ NMR data obtained for bone as it matures in a few-days-old chicken embryo to a several-weeks-old chicken. The pathway involves calcium and $(\mathrm{H}) \mathrm{PO}_{4}$ sorption at the $\mathrm{S}(\mathrm{P}) \mathrm{EE}$ site on $\mathrm{BSP}$ resulting in CaP nucleation. Analysis of crystal structures constrains the geometry of the proposed active site on BSP by the requirement for an epitaxial match with the apatite crystal structure. The equilateral triangle geometry for the acidic functional groups constituting the active site is proposed to be common to BSP found in bone-matrix, to synthetic silicate-based bioceramic prosthetic materials, and to opaline marine sediments.

\section{ACKNOWLEDGMENTS}

This work was supported by NSF Grants EAR 0346689, EAR 0208036, and by faculty start-up funds from the Graduate School and the Department of Geology and Geophysics, University of Wisconsin-Madison. The silica bioceramic work was funded from 1998-2000 by NSF post-doctoral fellowship grant EAR 9805673. I am indebted for insight provided and generous sharing of ideas by Dr. Jerry Ackerman; Dr. Melvin Glimcher, MD, PhD; Dr. Fawzy Saad; Dr. Erdjan Salih; and Dr. Yaotang Wu at Harvard Medical School and the Children's Hospital, Boston; and with Professor Michel Anseau, University of Mons-Hainaut, and Belgium. I also thank Dr. John Apps, Dr. H. C. W. Skinner and an anonymous reviewer for their constructive and useful comments.

\section{REFERENCES}

Alam, T., 1999, Ab Initio calculations of 31P NMR chemical shielding anisotropy tensors in phosphates: the effect of geometry on shielding, in Facelli, J. C., and de Dios, A. C., editors, Modeling NMR Chemical Shifts: ACS Washington, D. C., Chapter 22.

Alam, T. M., 1998, Ab Initio calculations of Nuclear Magnetic Resonance Chemical shift anisotropy Tensors, Sandia Report \# SAND98-2053: Sandia National Laboratories, p. 35.

Anseau, M. R., Leung, J. P., Sahai, N., and Saddle, T. W., 2005, Interactions of silicate ions with Zinc(II) and Aluminum (III) in alkaline aqueous solution: Inorganic Chemistry, v. 44, p. 8023-8032.

Baturin, G. N., 2000, Formation and evolution of phosphorite grains and nodules on the Namibian Shelf, from recent to Pleistocene, in Glenn, C. R., Prévôt-Lucas, L., and Luca, J., editors, Marine Authigenesis: From Global to Microbial: Tulsa, Oklahoma, SEPM Special Publication No. 66, SEPM, p. 185-120.

Bode, B. M., and Gordon, M. S., 1998, MacMolPlt: A graphical user interface for GAMESS: Journal of Molecular Graphics and Modeling, v. 16, p. 133-138.

Endo, A., and Glimcher, M. J., 1986, The potential role of phosphoproteins in the in vitro calcification of bone collagen: Transactions of the $32^{\text {nd }}$ Annual Meeting: Orthopaedic Research Society, v. 11, p. 221-223.

Frisch, M. J., Trucks, G. W., Schlegel, H. B., Scuseria, G. E., Robb, M. A., Cheeseman, J. R., Zakrzewski, V. G., Montgomery, J. A. Jr., Stratmann, R. E., Burant, J. C., Dapprich, S., Millam, J. M., Daniels, A. D., Kudin, K. N., Strain, M. C., Farkas, O., Tomasi, J., Barone, V., Cossi, M., Cammi, R., Mennucci, B., Pomelli, C., Adamo, C., Clifford, S., Ochterski, J., Petersson, G. A., Ayala, P. Y., Cui, Q., Morokuma, K., Malick, D. K., Rabuck, A. D., Raghavachari, K., Foresman, J. B., Cioslowski, J.,Ortiz, J. V., Baboul, A. G., Stefanov, B. B., Liu, G., Liashenko, A., Piskorz, P., Komaromi, I., Gomperts, R., Martin, R. L., Fox, D. J., Keith, T., Al-Laham, M. A., Peng, C. Y., Nanayakkara, A., Challacombe, M., Gill, P. M. W., Johnson, B., Chen W., Wong, M. W., Andres, J. L., Gonzalez, C., Head-Gordon, M., Replogle, E. S., and Pople, J. A., 1998, Gaussian 98, Revision A.9: Pittsburgh, Pennsylvania, Gaussian, Inc.

Froelich, P. N., Arthur, M. A., Burnett, W. C., Deakin, M., Hensley, V., Jahnke, R., Kaul, L., Kim, K. H., Roe, K., Soutar, A., and Vathakanon, C., 1988, Early diagenesis of organic matter in Peru continental margin sediments: Phosphorite precipitation: Marine Geology, v. 80, p. 309-343.

Glimcher, M. J., 1984, Recent studies of the mineral phase in bone and its possible linkage to the organic matrix by protein-bound phosphate bonds: Philosophical Transactions of the Royal Society London B, v. 304 , p. $479-508$.

1989, Mechanism of calcification: role of collagen fibrils and collagen-phosphoprotein complexes in vitro and in vivo: Anatomical Record, v. 224, p. 139-153.

1998, The nature of the mineral phase in bone: biological and clinical implications, in Metabolic Bone Disease and Clinically Related Disorders, Avioli, L. V., and Krane, S. M., editors, $3^{\text {rd }}$ Ed., 23: New York, Academic Press, 811 p. 
Hehre, W., Radom, J. L., Schleyer, P. V., and Pople, J., 1986, Ab Initio Molecular Orbital Theory: New York, New York, Wiley, 548 p.

Hench, L. L., 1998 Bioceramics: A forecast for the future: Biomaterials, v. 19, p. 1419-1423.

Hunter, G. K., and Goldberg, H. A., 1994, Modulation of crystal formation by bone phosphoproteins: role of glutamic acid-rich sequences in the nucleation of hydroxyapatite by bone sialoprotein: Biochemistry Journal, v. 302, p. 175-179.

Jarvis, I., Burnett, W. C., Nathan, Y., Almbaydin, F. S. M., Attia, A. K. M., Castro, L. N., Flicoteaux, R., Hilmy, M. E., Husain, V., Qutawnah, A. A., Serjani, A., and Zanin, Y. N., 1994, Phosphorite geochemistry: State-of-the-art and environmental concerns: Eclogae Geologicae Helvetiae, v. 87, p. 643-700.

Landis, W. J., Sanzone, C. F., Brickley-Parson, D., and Glimcher M. J., 1984, Radioautographic visualization and biochemical identification of O-phosphoserine- and O-phosphothreonine-containing phosphoproteins in mineralizing embryonic chick bone: Journal of Cell Biology, v. 98, 986-990.

Lee, S. L., Glonek, T., and Glimcher, M. J., 1983, ${ }^{31} \mathrm{P}$ nuclear magnetic resonance spectroscopic evidence for ternary complex formation of fetal dentin phosphoprotein with calcium and inorganic orthophosphate: Calcified Tissue International, v. 35, p. 815-818.

Lian, J. B., Roufosse, A. H., Reit, B., and Glimcher, M. J., 1982, Concentrations of osteocalcin and phosphoproteins as a function of mineral content and age in cortical bone: Calcified Tissue International, v. 34, p. S82-S87.

Mason, J., 1993, Conventions for the reporting of nuclear magnetic shielding or shift tensors suggested by participants in the NATO ARW on NMR shielding constants at the University of Maryland, College Park, July 1992: Solid State Nuclear Magnetic Resonance, v. 2, p. 285-288.

Palmer, D., 2004, CrystalMaker. Interactive Crystallography for Macintosh. User's Guide: Oxfordshire, United Kingdom.

Rey, C., Shimizu, M., Collins, B., and Glimcher, M. J., 1991a, Resolution-enhanced Fourier transform infrared spectroscopy study of the environment of phosphate ion in the early deposits of a solid phase of calcium phosphate in bone and enamel and their evolution with age: 1 . Investigations in the $\mathrm{n}_{4} \mathrm{PO}_{4}$ domain: Calcified Tissue International, v. 46, p. 384-394.

- 1991b, Resolution-enhanced Fourier transform infrared spectroscopy study of the environment of phosphate ion in the early deposits of a solid phase of calcium phosphate in bone and enamel and their evolution with age: 2. Investigations in the $\mathrm{n}_{3} \mathrm{PO}_{4}$ domain: Calcified Tissue International, v. 49, p. 383-388.

Sahai N., 2002, Biomembrane phospholipid-oxide surface interactions: crystal chemical and thermodynamic basis: Journal of Colloid and Interface Science, v. 252, p. 309-319.

Sahai, N., 2003a, Silicon-organic interactions in the environment and in organisms, in Geochemical and Hydrological Reactivity of Heavy Metals in Soils, Kingery, W. L., and H. M. Selim, H. M., editors: Boca Raton, Florida, CRC Press, Chapter 6.

Sahai, N., 2003b, The effects of $\mathrm{Mg}^{2+}$ and $\mathrm{H}^{+}$on nucleation of authigenic apatite at silica surfaces: Geochimica et Cosmochimica Acta v. 67, p. 1017-1030.

Sahai, N., and Tossell, J. A., 2000, Molecular orbital study of apatite $\left(\mathrm{Ca}_{5}\left(\mathrm{PO}_{4}\right)_{3} \mathrm{OH}\right)$ nucleation at silica bioceramic surfaces: Journal of Physical Chemistry B, v. 104, 4322-4321.

Salih, E., and Flückiger R., 2004, Complete topographical distribution of both the in vivo and in vitro phosphorylation sites of bone sialoprotein and their biological significance: Journal of Biological Chemistry, v. 279, p. 19808-19815.

Schmidt, M. W., Baldridge, K. K., Boatz, J. A., Elbert, S. T., Gordon, M. S., Jensen, J. H., Koseki, S., Matsunaga, N., Nguyen K. A., Su S. J., Windus, T. L., Dupuis, M., and Montgomery, J. A., 1993, General atomic and molecular electronic structure system: Journal of Computational Chemistry, v. 14, p. 1347-1363.

Stevens, W. J., Krauss, M., Basch, H., and Jansen, P. G., 1992, Relativistic compact effective core potentials and efficient shared exponent basis sets for the third, fourth and fifth row atoms: Canadian Journal of Chemistry, v. 70, p. 612-630.

Suga, T., and Okabe, N., 1996, Aqua(L-O-serine phosphato)calcium(II): Acta Crystallographica C, v. 52, p. 1894-1896.

Tye, C. E., Rattray, K. E., Warner, K. J., Gordon, J. A. R., Sodek, J., Hunter, G. K., and Goldberg, H. A., 2003, Delineation of the hydroxyapatite-nucleating domains of bone sialoprotein: Journal of Biological Chemistry, v. 278, p. 7949-7955.

Van Cappellen, P., ms, 1991, The formation of marine apatite: Ph. D. thesis, Yale University, New Haven, Connecticut.

Veis, A., 2003, Mineralization in organic matrix frameworks, in Dove, P. M., De Yoreo, J. J., and Weiner, S., editors, Biomineralization: Washington, D. C., Mineralogical Society of America, Reviews In Mineralogy and Geochemistry Series, Series Editor J. J. Rosso, v. 54, Chapter 9, p. 249-283.

Wolinski, K., Hinton, J. F., and Pulay, P., 1992, Efficient implementation of the gauge-dependent atomic orbital method for NMR chemical shift calculations: Journal of the American Chemical Society, v. 112, p. 8251-8260.

Wu, Y., Ackerman, J. L., Strawich, E. S., Rey, C. C., and Glimcher, M. J., 2000, Early phase bone formation studied by solid state ${ }^{1} \mathrm{H}_{-}{ }^{31} \mathrm{P}$ differential crosspolarization/magic angle spinning NMR spectroscopy: Proceedings of the International Society of Magnetic Resonance in Medicine, v. 8, p. 602.

Wu, Y., Ackerman, J. L., Strawich, E. S., Rey, C., Kim, H. M., and Glimcher, M. J., 2003, Phosphate ions in bone: Identification of a calcium-organic complex by 31P solid state NMR spectroscopy at early stages of mineralization: Calcified Tissue Inernational, v. 72, p. 610-626. 